\title{
Head of Village Participation in Thematic Village Policy in Pamekasan District
}

\author{
Rahmat Kurniadi Suroso $^{1}$, Agus Sukristyanto ${ }^{2}$, Bambang Kusbandrijo ${ }^{2}$ \\ ${ }^{1}$ Pamekasan sub Distric, Pamekasan Regency Government, Pamekasan, Indonesia \\ ${ }^{2}$ Political and Social Science Faculty, 17 August University Surabaya, Surabaya, Indonesia \\ Email address: \\ carakapmk@gmail.com (R. K. Suroso), agussukris@untag-sby.ac.id (A. Sukristyanto),b_kusbanrijo@untag-sby.ac.id (B. Kusbandrijo) \\ ${ }^{*}$ Corresponding author
}

\section{To cite this article:}

Rahmat Kurniadi Suroso, Agus Sukristyanto, Bambang Kusbandrijo. Head of Village Participation in Thematic Village Policy in Pamekasan District. Journal of Public Policy and Administration. Vol. 4, No. 4, 2020, pp. 85-94. doi: 10.11648/j.jppa.20200404.14

Received: November 7, 2020; Accepted: December 25, 2020; Published: December 31, 2020

\begin{abstract}
Thematic Village Policy (KDT) is one of the priority policies of the Pamekasan Regency Government in the 2018-2023 Regional Medium-Term Development Plan (RPJMD). This policy emphasizes its implementation in the village area, so it is clearly needed the support and participation of the head of village as the leader at the village level to make it happen. One year after the launch of the program, the significance of this program was not yet apparent, so researchers were interested in gathering head of villages in KDT. This qualitative research using interview method used 4 informants from villages that had different qualifications, namely the Independent, Advanced, Developing and Disadvantaged Villages selected based on the southern, central and northern regions of Pamekasan Regency. KDT did not invite many head of villages, and the technical guidelines had not been developed properly, but the participation of head of villages as a whole was very high, meaning that all villages could realize KDT, according to a qualitative agreement, participatory participation was low, because there were findings that appeared not based on a complete understanding with regard to the policy concept, it is therefore agreed that standard negotiations be made, optimizing the driving factors and inhibiting factors, and it is necessary to replicate the ideal model of head of village election so that it is more optimal.
\end{abstract}

Keywords: Participation, Policy, Village, Thematic

\section{Introduction}

Pamekasan Regency, as one of 38 regencies / cities in East Java Province, is administratively divided into 13 Districts, 11 Sub-Districts and 178 Villages with various potentials.

On September 24, 2018, the leadership of "BERBAUR" was inaugurated together with 12 regional heads of East Java who were elected in the Regional Head Election (Pilkada) simultaneously on June 27, 2018 with H. Baddrut Tamam, S.Psi. as Regents of Pamekasan and Raja'e, S.Hi. as Deputy Regent of Pamekasan.

To realize its political promises, after discussing with the DPRD and public discussion with other shareholders, on 1 April 2019, the Pamekasan Regency Medium Term Development Plan (RPJMD) 2018-2023 was set and amended in the 2019 Pamekasan Regency Regional Gazette. Number 9 with Regional Regulations Number Pamekasan
Regency Number 58-9 / 2019.

Based on Law Number 25 of 2004 concerning the National Planning System, since the date of its stipulation, this RPJMD can already be used as the basis for budget planning, starting from the current budget period, namely with the mechanism for Changing the Regional Budget (P-APBD) of the 2019 Budget Year, and in the following fiscal year.

In the RPJMD, it is stated that the vision to be achieved in the next five years is "Prosperous Prosperity from the Bottom, Evenly, Sustainably Based on Religious Values.". [16].

To make it happen, the vision is outlined in 5 missions, 7 goals and 17 targets which form the basis of the District Government in determining the strategy and direction of development policy.

Based on the goals and objectives to be achieved in the medium-term development, and taking into account the 
strategy and direction of development policy; then 10 Basic Agendas are prepared which are the implementation of the political promises of the Regent and Deputy Regent of Pamekasan in 2018-2023 as follows: (1) Smart and Smart Children / Pickles, (2) Free / Healthy Health, (3) Smart and Independent Villages / Cermatic Villages, (4) Road and Bridge Infrastructure and Area / Rujak Corek Arrangement, (5) One Water Tank Truck and Village / Strungking Village Drinking Water Network, (6) Welfare of Honorary Teachers, Ngaji Teachers, Guardians of Tombs, Burial Diggers, Modin and Posyandu Cadres / Tekker Pandan, (7) Fostering of Ten Thousand New Entrepreneurs and Prospective New Entrepreneurs / Blue Handkerchiefs, (8) Bureaucracy Transformation based on Good Governance / Tette Chips, (9) Integrated Licensing Services \& Fast and Easy Population Based Administration (Excellent Service) / Ji Dulasis, and (10) Welfare and Happy Farmers and Fishermen / Tanean Lanjheng. [16].

The main role of the head of village in leading the village government, giving color in the village administration, even his policy is very decisive before the law.

From these conditions, the author is interested in examining the Participation of the Head of village in the Implementation of Thematic Village Policies in Pamekasan Regency.

Based on the description on the background of the research above, the formulation of the problem in this study are: (a) What are the Conditions of Existing Participation of Head of villages in Thematic Village Policy Implementation in Pamekasan Regency? (b) What factors influence the Participation of Head of villages in Implementing Thematic Village Policies in Pamekasan District? (c) What is the Ideal Model for Head of village Participation in Thematic Village Policy Implementation in Pamekasan Regency?

The research objectives to be achieved in connection with this research are: (a) To identify the Existing Condition of Head of village Participation in Thematic Village Policy Implementation in Pamekasan Regency; (b) To identify inhibiting factors and supporters of the head of village in Implementing Thematic Villages in Pamekasan Regency; (c) To formulate an ideal model of participation of Village Leaders in Participating in the Implementation of Thematic Village Policies in Pamekasan Regency.

\section{Literature Review}

In this study 3 theories will be presented that will be used as scalpel in this research, including:

\subsection{Policy Implementation Theory}

In Weimer and Vining's view in Subarsono says taht there are three groups of large variables that can influence the successful implementation of a program, namely: (a) The logic of the policy; (b) This is so that a policy that is determined is reasonable and has theoretical support. We can think of the logic of a policy as well as the logical relationship of a hypothesis. This means that the contents of a policy or program must cover various aspects that can enable the policy or program to be implemented at a practical level. (c) The environment in which the policy is operated; and The environment in which the policy is operated will influence the successful implementation of a policy. What is meant by this environment includes the social, political, economic, security, and physical or geographical environment. A policy can be successfully implemented in a certain area, but apparently failed to be implemented in another area, due to different environmental conditions. (d) The ability of the policy implementor. [10].

The success of a policy can be influenced by the level of competence and skills of the policy implementors.

\subsection{Theory of Participation}

Judging from the origin of the word, the word participation comes from the English word "participation" which means taking part, participation, while in the Big Indonesian Dictionary, Participation is the participation of a person in an activity or taking part or participating.

Slamet says that participation means the active participation of a person or group of people from the process of formulating needs, planning, to the stage of implementing activities either through thought or directly in physical form [9]. I Nyoman Sumaryadi defines Participation as the participation of a person or group of people in the development process both in the form of statements and in the form of activities by giving thought, energy, time, expertise, capital and or material input, as well as participating in and enjoying the results development results [11]. Fasli Djalal and Dedi Supriadi, said that participation can also mean that decision makers suggest that groups or communities be involved in the form of delivering suggestions and opinions, goods, skills, materials and services [3]. Participation can also mean that groups recognize their own problems, examine their choices, make decisions, and solve problems.

According to Sundariningrum classifying participation into 2 (two) based on the way of involvement, namely: Direct Participation, namely participation that occurs when individuals display certain activities in the participation process. This participation occurs when everyone can put forward their views, discuss the subject matter, raise objections to the wishes of others or their words, and indirect participation, which is participation that occurs when individuals delegate their participation rights [12]. Siti Irene Astuti D quotes Cohen and Uphoff, distinguishing patenting into four types, namely: (1) Participation in decision making, where participation is mainly related to determining alternatives with the community relating to ideas or ideas that concern the common interest. The manifestations of participation in decision making include, among others, contributing ideas or thoughts, attendance at meetings, discussions and responses or rejection of the programs offered. (2) Participation in implementation, where participation in implementation includes mobilizing financial resources, administrative activities, coordination and program 
description. Participation in the implementation is a continuation of the plan that had been previously conceived both related to planning, implementation and objectives. (3) Participation in taking utilization. Where participation in taking benefits cannot be separated from the results of the implementation that has been achieved both related to quality and quantity. In terms of quality can be seen from the output, while in terms of quantity can be seen from the percentage of program success. (4) Participation in evaluation, where participation in this evaluation relates to the implementation of the program that has been planned previously. Participation in this evaluation aims to determine the achievement of programs that have been previously planned [8].

From some of the definitions above, it can be concluded that participation is the involvement of an individual or group in achieving the goals and the sharing of authority or shared responsibility.

According to Effendi, cited by Siti Irene Astuti D also says that the form of participation is divided into:

\subsubsection{Vertical Participation}

Vertical participation occurs in the form of certain conditions where the community is involved or takes part in a program of another party, in relationships where the community is a subordinate, follower, or client status.

\subsubsection{Horizontal Participation}

Horizontal participation, the community has an initiative where each member or group of people participates horizontally with one another.

There are several expert opinions that distinguish levels of participation in society. Robert Chambers (2005: 105) mentions that there are 3 models of participation proposed by experts [7]. As according to Arnstein who stated that there are 8 levels of community participation, in contrast to Kenji and Greenwood, in dividing the level of participation, it is narrowed down to 5 levels. Whereas VeneKlasen and Miller share 7 levels of participation.

From some theoretical opinions, basically the desired goal of community participation is the emergence of community independence in controlling or mobilizing themselves. Agus Sukristyanto says that Partisan alignment tends to last a long time that can give rise to the phenomenon of identity politics [1].

\subsection{Leadership Theory}

Leadership as Moejiono says is an applied science of social sciences, because its principles and formulations are expected to bring benefits to human welfare [5]. There are many understandings put forward by experts according to their respective points of view, the definitions indicate some similarities.

According to Tead; Terry; Hoyt in Kartono Understanding Leadership is the activity or art of influencing others to want to work together based on the person's ability to guide others in achieving the goals desired by the group [4]. According to Young, still in Kartono, Understanding Leadership is a form of dominance based on personal ability that is able to encourage or invite others to do something based on acceptance by the group, and has special expertise appropriate for a particular situation [4]. Moejiono views that leadership is actually as a result of one-way influence, because leaders may have certain qualities that distinguish themselves from their followers [5].

Moejiono says Volunteer theorists (compliance induction theorists) tend to view leadership as coercing or insisting on influence indirectly and as a means to form groups according to the wishes of the leader [5]. From some of the definitions above it can be concluded that leadership is the ability to influence other people, subordinates or groups, the ability to direct the behavior of subordinates or groups, has the ability or special expertise in the field desired by the group, to achieve organizational or group goals. Leadership is concerned with handling change, setting direction by developing a vision of the future then uniting, communicating and inspiring people in the organization to achieve goals. The ability to direct others to achieve their intended goals cannot be done easily, if a person has no birth talent, expertise or references from past actions in the field of leadership.

Many studies have been conducted by leadership experts, and have produced large theoretical studies, and become the basis of thinking in subsequent studies, such as Davis, A Dale Tempe (1993); Hersey \& blankart (1998) which inspired the birth of the nature and situational theory. Furthermore behavior theory is presented by $\mathrm{X} \& \mathrm{Y}$ theory, Ohio State Studies (1945) and the University of Michigan, Grid Management and Likert. Then the Situation Theory (Bennis, 1981), Transactional Theory (Burn, 1978). There are also contemporary leadership theories that are divided into Charismatic Leadership (Conger \& Kanungo, 1988), Transformational Leadership (Bass, 1985), and Visionary Leadership (Pinto, Jeffrey K. Et all, 1998).

Each leadership expert arranges the paradigm according to the needs of the approach and various perceptions of simplification and modernization of thought. As an example of one of the Leadership experts, Suryadi classifies leadership theory into 4 (four) consists of (1) Theory of Character consisting of: employee selection study approach and leader emergency approach; (2) behavior theory consists of: Leadership Continuation Theory, Two Demensional Theory, Supportive Theory and Grid Theory; (3) Situational Theory using the Fiedler Theory model, House-Path Goal Theory model, Vroom-Yelton-Jugo Theory Model, Hersey Model and Blanchard Theory. Furthermore, the last paradigm is Content Theory consists of: Charismatic Leadership, Visionary Leadership, Transactional Leadership [13].

\section{Research Procedures}

This research was carried out based on the research problem which is knowing the participation of the head of village in the implementation of Thematic Village policies in Pamekasan Regency.

The phenomenon of head of village participation in the 
implementation of district government policies is important to know, bearing in mind that until the end of October 2019, out of 178 villages in Pamekasan, only 1 village has implemented Thematic Village policies, namely Murtajih Village, Pademawu District, whereas according to Ministerial Regulation In State (Permendagri) Number 20 Year 2018 regarding Village Financial Management stated that the time of Amendment to APBDes of the relevant year is October. If examined more deeply, then we will come to an important reason, why the head of villages did not immediately implement the Pamekasan Regency government policy. This is what needs to get a more detailed assessment. According to Ritzer, the social behavior paradigm focuses its attention on the relationship between the individual and his environment, both the environment of social objects and non-social objects [6]. The principle that dominates the relationship between individuals and social objects is the same as the principle that dominates the relationship between individuals and non-social objects.

This paradigm focuses on the process of interaction of individuals with their environment. The relationship between the effects of behavior that occurs in the environment of the actor, as well as how the actor and his environment perform transactions functions and values.

The social behavior paradigm can use the methods used by other paradigms such as interviews and observations of aspects of the study.

Creswell says that qualitative research is an interpretive study, which places humans as the main subjects in social and cultural events [2]. This type of research is based on the phenomenological philosophy of Edmund Husserl (1859-1928) which was later developed by Max Weber (1864-1920) into sociology. In Weber's view, human behavior that appears is the consequences of a number of views or doctrines that live in the heads of human beings. Thus, there are a number of meanings, limits or complexities of meaning that live in the heads of human beings, which form explicitly expressed behavior.

Based on the conclusions above, the qualitative paradigm holds that social, cultural and human behavior phenomena are not enough to record things that are clearly visible, but must also look at the whole in the totality of the context, because behavior is inseparable from the context behind it, and cannot can be simplified into single laws that are deterministic and context-free.

So, to answer the problem formulation in this study, researchers used a qualitative descriptive approach. This study uses the main research object: the Head of village as an important actor in the Implementation of Thematic Village Policy in Pamekasan Regency.

In connection with the village cluster that has been determined by the central government with the Village Development Index (IDM), where in Pamekasan Regency consists of 4 clusters, namely the Independent, Advanced, Developing and Lagging Villages, each cluster is taken 1 village with the Purposive Sampling model, where the location the target has been determined in advance by the researcher.nd Transformational Leadership.

For the Desa Mandiri cluster: Panempan Village, Pamekasan District, for the Desa Maju cluster: Murtajih Village, Pademawu District; for the Developing Village cluster: Somalang Village, Pakong District and for the Disadvantaged Village Cluster: Lesong Laok Village, Batumarmar District.

Data collection methods used by researchers in this study are as follows: this interview is conducted anywhere that is deemed to be able to provide and explore as much information as possible at the research location. Interviews were conducted with the initial informants as well as several other informants to gather information and data needed in connection with the Participation of the Head of village in Implementing Thematic Village policies in Pamekasan Regency.

Through this documentation, trick description is obtained. This technique is intended to process secondary data such as letters, archives and documents from relevant agencies, which relate to the data needed by researchers. While recording the writing data is done by utilizing research instruments, namely files, notes, interview write-up mapping, photograpichs, sound.

The use of this documentation technique is to support the validity of data and information obtained from informants relating to research material at the Community Empowerment Agency and Pamekasan District Government.

Data analysis is an effort to search for and obey systematically the notes of observations, interviews and others to improve the understanding of researchers In qualitative research, analysis is carried out from the beginning and throughout the research process takes place or whenever an event that is the focus of research is finished recorded and forgotten in the form of field reports.

\section{Discussion Result}

The victory of the BERBAUR couple in the contestation of the Pamekasan Regency elections in 2018 brought a breath of fresh concepts of change in governance.

The Election Commission (KPU) Pamekasan, East Java, Friday (10/8/2018) afternoon set Badrut Tamam and Raja'e (Blended) as a pair of elected Regent and Deputy Regent of Pamekasan, the results of the June 27, 2018 elections after winning a dispute in the Constitutional Court against a partner.

Based on the manual recapitulation of the Pamekasan KPU, the pairs of candidates for regent and deputy regent of Pamekasan Badrut Tamam and Raja'e (Blend) won 29,142 votes from Kholilurrahman and Fathor Rohman (Kholifah) pairs in the simultaneous local election held on Wednesday (27/6). sequence number 1, namely Badrut Tamam-Raja'e (Blended) is known to have received as many as 257,738 votes, while candidate pair number 2, namely $\mathrm{KH}$ Kholilurrahman-Fathor Rohman (Kholifah) won support as many as 228,596 votes.

On September 24, 2018, at the Grahadi State Building in 
Surabaya, the leadership of "BERBAUR" was inaugurated by the Governor of East Java, DR. H. Soekarwo together with 12 regional heads in East Java who were elected in the Regional Head Election (pilkada) simultaneously on June 27, 2018 with H. Baddrut Tamam, S.Psi. as Regents of Pamekasan and Raja'e, S.Hi. as Deputy Regent of Pamekasan.

Based on Law Number 25 of 2004 concerning the National Development Planning System and Law Number 32 of 2004 concerning Regional Governments as amended the last time with Law Number 23 of 2014, has mandated the Regional Governments to draw up regional development plans, including Regional Long-Term Development Plan (RPJPD) with a period of 20 years, Regional Medium-Term Development Plan(RPJMD) with a term of 5 years, and the Local Government Work Plan (RKPD) with a period of 1 year.

The regional development plan becomes an integral part of the national development planning system. Regional development plans are prepared to ensure the linkage and consistency between planning, budgeting, implementation and supervision, so that the preparation must be carried out in an integrated, measurable, and carried out in a sustainable manner. Article 19 paragraph (2) of Law Number 25 Year 2004 states that the RPJMD shall be stipulated by a Regional Head Regulation no later than 3 (three) months after the
Regional Head is appointed. Meanwhile in Article 150 paragraph (3) letter c of Law Number 32 Year 2004 it is stated that the RPJMD is stipulated by a Regional Regulation based on Government Regulation. [14].

In this regard, the Government has established Government Regulation No. 8/2008 concerning Stages, Procedures for Preparation, Control and Evaluation of the Implementation of Regional Development Plans. Wherein this Government Regulation states that the RPJMD is set no later than 6 months after the Regional Head is appointed with a Regional Regulation. [15].

As a consequence of the regulation, the Blend team formed the Transition Team to realize campaign promises and make it a content in the Pamekasan Regency Medium Term Development Plan (RPJMD) 2018-2023.

As a public policy, the 2018-2023 Regency RPJMD has gone through the process as regulated in the Minister of Home Affairs Regulation (Permendagri) No. 86 of 2017 concerning Procedures for Planning, Control and Evaluation of Regional Development, Procedures for Evaluation of Regional Regulation Drafting on Regional Long-Term Development Plans And Regional Medium-Term Development Plans, As well as Procedures for Changing Regional Long-Term Development Plans, Regional Medium-Term Development Plans, and Regional Government Work Plans, including the schedule as follows:

Table 1. Schedule for the Development of RPJMD 2018-2023

\begin{tabular}{l} 
Stage \\
Inauguration of Selected KDH / WKDH \\
Preparation of the Initial RPJMD Draft \\
Public Consultation \\
Submission of Ranwal RPJMD to KDH \\
Submission of Ranwal RPJMD to DPRD \\
Ranwal RPJMD Discussion and Agreement \\
Consultation Ranwal RPJMD to Province (Governor) \\
Submission of Consultation results by Province (Governor) and \\
Improvement of RPJMD Ranwal \\
Submission of a Pamekasan Regent Circular on the Compilation of the \\
2018-2023 Regional Strategic Plan Renstra \\
Preparation of Regional Renstra Strategic Plan based on Improvement of \\
RPJMD Ranwal \\
The Regional Apparatus Forum for the Preparation of the Initial Strategic \\
Plan \\
Preparation of the RPJMD Plan \\
Submission of the RPJMD Plan to KDH through the Regional Secretary \\
Approval of the implementation of the RPJMD Musrenbang KDH \\
Implementation of RPJMD Musrenbang \\
Formulation of Final Design \\
Submitting the Draft Regional Regulation on RPJMD to the Regional \\
Secretary through the Legal Department \\
Submission of Draft Regional Regulation on RPJMD to DPRD \\
Discussion on Draft Regional Regulation on RPJMD with DPRD \\
Provincial Regulation Draft Evaluation (Governor) \\
Determination of RPJMD \\
\hline
\end{tabular}

$\begin{array}{ll}\text { Time Implementation } & \text { Keterangan } \\ \begin{array}{l}\text { September 24, 2018 } \\ \text { October 1, 2018 }\end{array} & \text { In the Grahadi State Building Surabaya } \\ \begin{array}{l}\text { October 8-12 2018 } \\ \text { October 23, 2018 }\end{array} & \begin{array}{l}\text { no later than } 30 \text { days after preparation of the } \\ \text { RPJMD Ranwal }\end{array} \\ \text { november 5, 2018 } & \begin{array}{l}\text { no later than 40 days after KDH's inauguration } \\ \text { Speaker of the DPRD } \\ \text { no later than 50 days after KDH's inauguration }\end{array} \\ \text { November 16, 2018 } & \text { Adjust to the schedule of the Province }\end{array}$

November 26, 2018

November 26-29, 2018

December 6, 2018

December 7, 2018

December 8, 2018

December 9, 2018

December 10, 2018

December 11-21, 2018

December 28, 2018

January 8, 2019

February 24, 2019

April 1, 2019 no later than 70 days after KDH's inauguration no later than 75 days after KDH's inauguration

no later than 90 days after KDH's inauguration

no later than 5 months after KDH's inauguration No later than 6 months after KDH's inauguration
After going through a joint DPRD study and public discussion with other stakeholders, on April 1, 2019 the Pamekasan Regency Medium Term Regional Development Plan (RPJMD) 2018-2023 was determined and announced in the Pamekasan Regency Gazette Year 2019 Number 9 with the Regional Regulation Register Number Pamekasan Regency Number 58-9 / 2019.

With its legal power, based on Law Number 25 of 2004 
concerning the National Planning System, then from the date of its stipulation, this RPJMD can already be used as the basis for budget planning, starting from the current budget period, namely with the mechanism for Changing Regional Budget and Revenue ( P-APBD) Fiscal Year 2019, as well as the following fiscal year.

The vision carried out in the 2018-2023 RPJMD is "Prosperous Prosperity from the Bottom, Evenly, Continuously Based on Religious Values." Furthermore, the vision is described in 5 missions, namely: (1) Strengthening the quality of Human Resources. (2) An Inclusive Economy Based on the Agriculture Sector and Supported by the Acceleration of Development in the Industrial, Trade and Other Potential Sectors. (3) Improved Governance and Public Services. (4) Meeting the Quality of Basic and Equitable and Sustainable Infrastructure. (5) Management of Social Potential, Cultural, Religious, Youth and Women's Values to Create a Harmonious and Prosperous Society.

These missions are then translated into 7 goals and 17 targets which form the basis of the Pamekasan Regency Government in determining the strategy and direction of development policy, as attached.

On the 3rd main agenda, to realize the Smart and Independent Villages (DesaCermat), as the implementation of Community and Village Empowerment affairs, is explained as follows: (1) Developing an independent village, through accelerating, repairing and improving infrastructure and empowering village communities desa Rp. 500 million - 1 billion per year; (2) Smart Village (Smart Village), which uses IT as a medium to support development towards village independence; (3) Implementation of One Village One Scholar Companion in the framework of increasing the capacity of HR to manage the utilization of the Village Fund; (4) Facilitating the establishment and development of BUMDes to optimize the management of superior products based on One Village One Product Village; (5) Revitalizing Thematic Villages based on One Village One Product.

The operationalization of the Thematic Village program is the responsibility of the Pamekasan Regency Community and Village Empowerment Office.

This program has become very important in its application, bearing in mind that the Pamekasan District Head has on various occasions always expressed the importance of the Thematic Village program. Based on these conditions, it can be seen that the attention of the leadership, in this case the Regent of Pamekasan, is very high, so that he always socializes the Thematic Village program, on various occasions, both in a series of formal and informal events.

As a policy sourced from the attention of the Regent-Deputy Regent Pamekasan, it is necessary to know the concept of thought related to this program. From several sources, it can be seen as follows:

From some of the documentation data above, there are some important keywords that we can relate to the Thematic Village Concept Design, namely: reviving the community's economy equally, one village one product, innovation, defining the economic potential of the village, Making the scale of priorities, The targets are clear, district governments can easily provide matching funds, accompanied by academics and regional research councils (DRD).

The 2018-2023 RPJMD emphasizes that the Program Supporting Regions are the Office of Community and Village Empowerment, under the Coordination of Government Assistant and People's Welfare or commonly known as Assistant I. Based on the results of interviews with the Head of the Community Empowerment Service, represented by the Head of Village Administration H. Muttaqin, S. Sos, M.Sc., Section Head of Institutional Empowerment, Nasirullah, SH., M.Sc. and the Village Community Empowerment, Nurul Hidayah, and Suparman Companion Program on February 10, 2020, located in the regional office of the Pemdes district office. unofficially, even the Head of DPMD has directly addressed the Regent of Pamekasan regarding this program. In general, the program was inspired by the concept of "One Village One Product" which was later developed with the support of the Village Fund / Village Fund Allocation (DD / ADD) in each village. Where the core of this program is an effort to improve the welfare of rural communities by maximizing local potential in their respective villages.

The Village Facilitators also said that before the thematic village program was launched, a village empowerment program had previously been carried out by conducting the Village Innovation Exchange, where villages could share experiences, discuss and convey obstacles in the empowerment of their villages.

Based on the study of leading commodity profiles based on One Village One Product (OVOP) conducted by the Bappeda of Pamekasan Regency in 2017, the commodity most cultivated in the Regency In general this study is very good to be used as a reference in Thematic Village (KDT) policies, but it needs to be deepened again, because the studies that appear are mostly based on sub-districts, not villages.

This research was conducted in 4 different villages based on the Village Development Index (IDM) in 2019 juxtaposed with the division of the planning area consisting of the South, Central and North Regions. The first location of this study was Panempan Village, the only village with the status of an Independent Village in IDM 2019 and located in the Pamekasan Subdistrict, South Pamekasan District. Bordered by Kanginan Village in the north, Ceguk Village in the south, Buddih Village and Kanginan Village in the east and Laden Village and Panglegur Village in the west, Panempan Village has an area of $0.82 \mathrm{Km}^{2}$ or around $3.10 \%$ of the total Pamekasan District Area which has an area of $26.47 \mathrm{Km}^{2}$. The village is located at an altitude of 10 meters above sea level is $0.7 \mathrm{Km}$ from the Pamekasan District Office and 1 $\mathrm{Km}$ from the Regional General Hospital dr. $\mathrm{H}$. SlametMartodirdjo(SMART) and the nearest Puskesmas. This village has 3 hamlets with the head of village Drs. Moh. Fandi and population of 2,513 inhabitants.

The head of village who is currently in charge has actually led the village in the 2003-2008 period, followed by his wife Hj. Masidah in 2009-2015, and held again by Drs. Moh. 
Fandi for the period 2016-2022. The village focuses its attention on village market governance managed by Delta Mulia's Village-Owned Enterprises (BUMDes). Before the BUMDes was established, from 2015 to 2018, the management of the Village Market was handed over to a third party, according to the head of village, to carry out an orderly administration of market revenues and expenditures, so that if there was an inspection, the manager could be held accountable properly. During the period of 2015-2018, through this third party, Panempan Village received Village Original Income (PADes) of 35 Million Rupiah annually. But in its development, market governance shows unfavorable things, besides there is no increase in PADes every year, market governance is also getting less good, this is indicated by poorly maintained markets, poorly maintained and seemingly dirty markets, less lighting, less frequent traders loss of merchandise, irregular merchant position and inadequate parking facilities.

The head of village thinks, if this condition continues, will bring things that are not good for the village, and took the initiative to manage the market with the BUMDes model. This plan was then conveyed to several village leaders and the leaders welcomed the head of village's plan.

Then on November 6, 2017, a Village Deliberation was held to form a Village-Owned Enterprise (BUMDes) under the name BUMDes Delta Mulia, which was followed up with the issuance of Village Regulation No. 02 of 2017 on November 13, 2017 concerning the Establishment, Management and Management and Disbanding of the Village Owned Enterprises

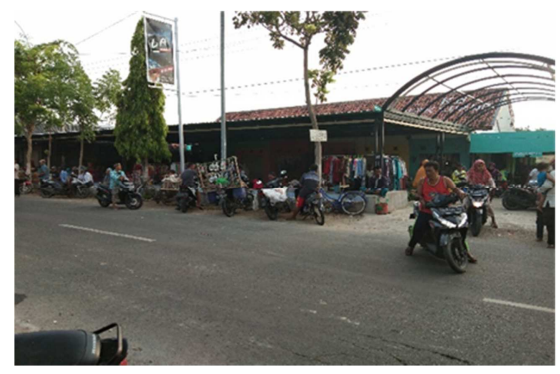

Figure 1. Picture of Panempan Village Market before and after managed by BUMDes Source: Documentation of Panempan Village, 2020.

In the initial period of its establishment, in 2018, BUMDes Delta Mulia was supported with an initial fund of 40 million for operational costs, and in 2019, it has produced many things in the form of income to the village treasury, as well as other physical market improvements, such as 35 million PADes Rupiah, the market is neat, the market is maintained and not slums, lighting at night is sufficient, there are no more traderslosing merchandise, orderly and orderly traders, adequate parking facilities, supporting 11 employees, building 4 shops and 5 new market stalls, and building a roof for Lesbian traders.

Murtajih Village is the second location of this study, including in the Maju Village and in the Pademawu Sub-District, South PamekasanDistrict. Bordered by Dasok and Buddagan Villages in the north, Sumedangan and
Pademawu Villages in the south, Dasok and Bunder Villages in the east, and Buddagan and Lemper Villages in the west, Murtajih Village has an area of $3.23 \mathrm{Km}^{2}$ or around $4.49 \%$ of the Total District of Pademawu District which has an area of $71.90 \mathrm{Km}^{2}$. The village, which is 8 meters above sea level, is $1 \mathrm{Km}$ from the Pademawu District Office and is occupied by the Pademawu Community Health Center, one of the Health Centers in Pademawu District. This village has 8 hamlets with a population of 6,166 people. Murtajih Village is a village that has a variety of potentials, starting from agriculture, to tourism potential. The first head of village is $\mathrm{R}$. Astro Brojodiguno. After his death, his son Moh. Ali Manshuri as the second head of village in the period 1965-1975. Followed by the third head of village Moh. Ra'I who ruled in 1975-2009. In the Pilkades on June 25, 2009, Drs. H. M. Rasyidi as head of village in the 2009-2015 period and in the September 9, 2015 pilkades was re-elected for the 2015-2021 period.

The definitive head of village has just died, Alm. Drs. H.M. Rasyidi, and to fill the vacancy, then filled by Acting (Acting) Head of the Village Mr. Jazuli then BPD chose an interim replacement (PAW) Hj. EndangSuciati, S.Pd. until the term of office ends (2020-2021).

The village is currently focusing its attention on the development of an integrated tourism area of 5 hectares which will be developed by various types of tourism, with the regional plan as shown below

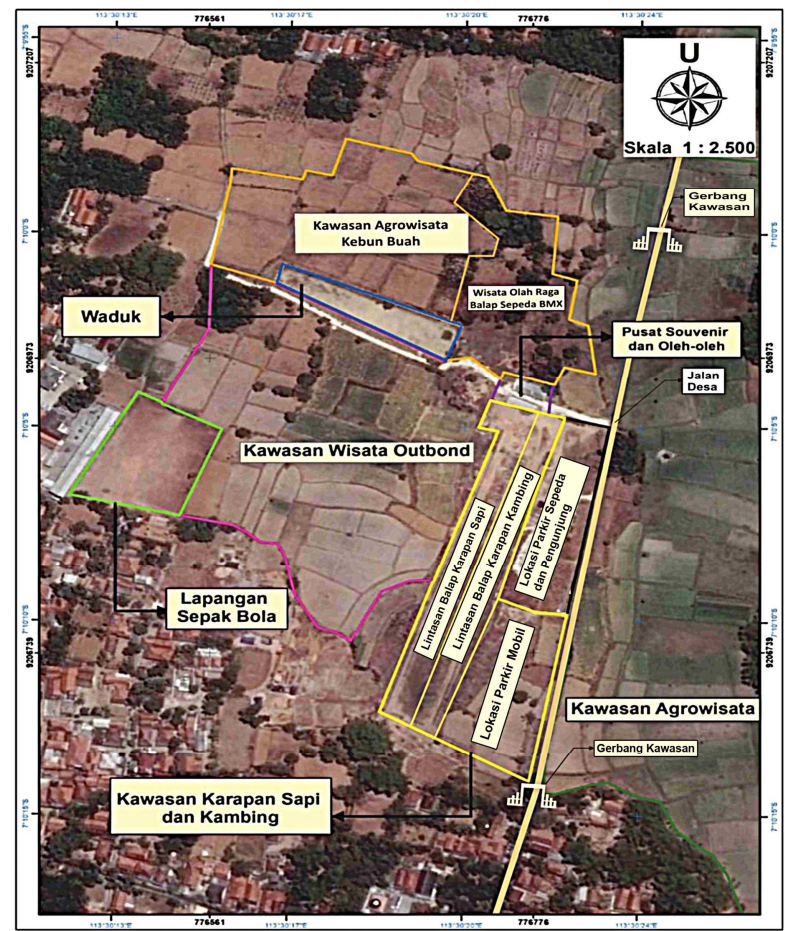

Figure 2. Map of Murtajih Integrated Tourism Village AreaSource: Documentation of Murtajih Village, 2020.

In 2018, together with the beginning of the construction of several physical buildings at thelocation, BUMDes was formed, but due to financial commitment factors, this initial BUMDes was inactive and during the Acting Head of Jasuli 
Village, the BUMDes management was rejuvenated in 2019. After several exposures in front of the Regent and the leadership of the regional apparatus, it was agreed that Murtajih Village would become a Pilot Thematic Village with the theme of the Tourism Village and be supported by several related regional instruments, such as the Office of Community Empowerment and the Village as the coordinator, the Office of Tourism and Culture, the Office of the Environment Life, Public Works and Spatial Planning Office, Youth and Sports Agency, and several other supporting regional devices.

In the integrated tourism area, several village market stalls have been built, fruit parks, mini cross arenas, KarapanSapi and Goat Fields, Ponds and water games facilities, and Gazebos that have been built jointly between the village government and OPD are related to the concept of pilot tourism gods. In general, development in integrated tourism areas is the following:

Somalang Village is the third location, included in the developing village and is in the Pakong Subdistrict, Central PamekasanRegion. Bordered by Palalang Village in the north, Klompang Timur Village in the south, Klompang Barat Village in seleh Barat and Ban-ban Village in the east, Somalang Village has an area of $0.98 \mathrm{Km}^{2}$ or around $5.14 \%$ of the Total District Area Pakong which has an area of 30.71 $\mathrm{Km}^{2}$. The village, located at an altitude of 238 meters above sea level, is $3.5 \mathrm{Km}$ from the Pakong District Office and 3 $\mathrm{Km}$ from the nearest Puskesmas. This village has 2 hamlets with the Head of village of the Woman, Siti SyakirinNikmah, S. AP. with a population of 1,111 inhabitants. This village is focusing on developing a water source known as Sumber Penang which will later be used as a family tourism vehicle.

This concept was inspired by the thematic village program echoed by the district government, but inthe meantime the village government is still in the process of forming a tourism awareness group (Pokdarwis) or BUMDes that will manage it In the previous fiscal year 2019, Somalang Village allocated a budget of 145 million rupiah for the construction of penang sources, and for 2020 the budget was being calculated because the APBDes were being calculated to adjust to the new budget policy. Until now Sumber Penang is still used traditionally by the local community as a public facility for community bathing and irrigating rice fields. There is no village income from this activity. Lesonglaok village is the location of the four studies, including the underdeveloped village and located in the Batumarmar District, North Pamekasan. Lesonglaok village has an area of $4.28 \mathrm{Km}^{2}$ or around $4.41 \%$ of the Total District of Batumarmar District which has an area of $97.05 \mathrm{Km}^{2}$. The village, which is 18 meters above sea level, is $20 \mathrm{Km}$ from the Batumarmar District Office and $20 \mathrm{Km}$ from the nearest Puskesmas. This village has 4 hamlets with the head of village $\mathrm{Hj}$. Suparti and population of 2,958 people. With the leadership of the new head of village, who was appointed in October 2019, the village government is committed to building a thematic-based onion village that becomes its flagship product in accordance with the results of the Village
Innovation Exchange in 2018 ago. Several plans for community empowerment including the establishment of BUMDes are being prepared. For the 2020 budget year, 50 million rupiah has been prepared for capital investment in BUMDes.

Interview Results, before entering into the core material of head of village participation, it is important to say in advance that participation is intertwined with policy implementation and leadership, so some questions will produce answers that relate to both. When asked about what the head of village knew about thematic village policies (question 1), 3 head of villages did not answer the substance of the question about understanding the thematic village policy concept (KDT), but directly to the field activities carried out in their respective villages, while 1 head of village conveyed the general concept of KDT. The head of village of Panempan told about the village market, its management, until the formation of the BUMDes and the latest conditions that have made the village market better. The head of village Murtajih told about the integrated tourism village area which has now begun to be built thanks to the support of various parties, both the provincial government, OPD KabupaenPamekasan, as well as those sourced from DD / ADD local villages. The Somalang Head of village told about the development that had begun in Sumber Penang, which was later planned to be utilized by the community, but would also be used as a vehicle for family tourism. Only the LesongLaok Village Chief answered this question well, by presenting the KDT concept as an effort to advance the village by optimizing its local potential, in this case LesongLaok Village would make Bawang Merah the main theme in the village.

Answering the question Where did KDT information get (Question 2), all head of villages answered that they had heard directly from the Bupati, the DPMD Head, the Camat, and several other DPOs in Pamekasan Regency, such as Bappeda and Disparbud. Although it is recognized that it is not on the specific agenda of KDT socialization, but in several meetings, these officials often mentioned KDT. KadesPanempan even said that he had read KDT delivered by the Regent through social media. From these answers it can be seen that the district and sub-district governments have conducted thematic village socialization, both at the district and sub-district level, who presented officials at the head of village level although not on the specific agenda of KDT socialization, but in delivering the material alluded to $\mathrm{KDT}$, it has even seen the use of social media in KDT socialization. From the explanation of the head of villages, the delivery by the Regent was done at the time. Regarding the question Is the information received can be understood (Question 3), all head of villages said they understood the purpose of the policy to improve the welfare of the community, only the Lesonglaok head of village stated that it was more specific, namely the strengthening of local village potential. This is important to know, because later it will affect the policies that will be taken in each village, where the head of villages are very dominant influence in policy making in the village. 
Even more important is that the head of villages understand only a general concept, while the technical, process and governance are not well understood. Regarding the question Are involved in the formulation of KDT (Question 4) as a whole the head of villages stated they were not involved in making DT policies. The head of villages consider KDT is a district policy, where the position of the village and the head of village as the object of the policy is in the position of implementing the policy made by the district government. Regarding the question What has been done in relation to the Implementation of KDT in the village (Question 5), the head of villages answered varied, because indeed the conditions of each village differed.

The Panempan Head of village stated that until now the KDT training in his village had reached the development of services carried out by BUMDes, in collaboration with banks and vertical agencies such as BRI and PT Pos Indonesia. BUMDes has been formed, is running well, year-end accountability is being carried out and is currently in the process of developing services. The Head of village of the Murtajih Village stated that the physical development in the Integrated Tourism Village Area is still ongoing, while the BUMDes of the management are still undergoing rearrangement after the old chairman resigned due to financial reasons, while the Tourism Awareness Group (Pokdarwis) has been formed and a decree has been submitted to the Tourism Office and Pamekasan Regency Culture, to support this, the village government strengthens the capabilities of its human resources by budgeting training for all the equipment and heads of hamlets, so that now all the devices and hamlet heads are able to operate computers.

The Somalang Head of village said that until now the physical construction at the Penang Sumber Location is still ongoing, while the BUMDes and Tourism Awareness Group (Pokdarwis) are still in the preparatory stages of formation, while the LesongLaok Head of village, said because it was only inaugurated in October 2019, the implementation DT is still in the preparation stage, both determining the village theme, its implementing organization and its follow-up policies, but specifically there has been an agreement with BPD to budget for equity participation to BUMDes which will be formed at 50 Million Rupiah. From these answers in general it can be concluded that there are 3 (three) KDT implementation models implemented in the village, the first is still in the planning process, the second has begun activities in the field and the third is the development model of existing activities.

Answering the question Do current themes really emerge after KDT has been socialized? (Question 6), the head of villages answered diverse.

Panempan Head of village and Murtajih Head of village stated that the thematic in their respective villages actually existed before KDT was delivered. When KDT is socialized, and it turns out that activities in the village have the same purpose, then the activity is made part of the KDT implementation.

While the Somalang Village said that the development of Sumber Penang was indeed inspired by KDT, while the
LesongLaok Village has yet to bring up the village thematic because it is in preparation.

When the question was deepened with regard to the mechanism for determining village themes, head of villages who already had themes in their village did not know the process and mechanism for determining the theme, but said that the idea of the village theme emerged from the head of village's idea which was followed up with the budgeting process in the APBDes.

Related to the question What benefits do villages receive with KDT? (Question 7), except for LesongLaok Village, the three head of villages stated that they benefited from KDT.

The Head of Panempan Village stated that he benefited from KDT, in addition to the Village's Original Income, which is currently at 35 million a year, the village market is cleaner and more beautiful, the village market management is better and even able to absorb 11 local workers. The head of village of Murtajih said he benefited from KDT, because besides Murtajih was better known by the outside community, his village assets were better and could benefit the community economically. The Somalang Head of village stated that the benefits of KDT aside from village assets were better, the community could better utilize the existence of Sumber Penang, while the LesongLaok Village Chief said that although he did not yet feel the benefits of KDT, he believed that the implementation of KDT would support the achievement of community welfare. Related questions How to evaluate KDT? (Question 8), Except for the Somalang and Lesonglaok Head of villages who have not yet conducted an evaluation, the other Head of villages answered varied according to the conditions in their respective villages.

The Head of Panempan Village stated that he ordered BUMDes as the village market thematic performer to conduct a public accountability forum at the end of the 2019 fiscal year, the responsibility material was handed over to participants a few days before it was carried out so that it could be read by the participants and the activities took place openly and democratically. So the head of village was directly involved in the KDT evaluation activities.

The head of village of Murtajih, who at that time was held by PJ by the village secretary Mr. Jazuli, evaluated the BUMDes, which since its establishment, did not carry out their duties properly. The results of his evaluation overhauled the old management and formed a new management to date. The head of village is directly involved in evaluating BUMDes implementing thematic village policies.

Answering the question Does KDT support and why? (Question 9) the head of villages generally answered supporting KDT, because apart from being an obligation of the village government to comply with government policies above, in this case the district government, would also benefit the village government, both in terms of asset conditions, improving the people's economy, and the opening of employment opportunities for the surrounding community.

When the question is deepened, what form of support? generally answered in the form of allocating some of the funds in the APBDes to realize thematic villages. 
Related to the question What are the Problems encountered in the implementation of KDT? (question 10) the head of villages answered, that the main problem in this KDT was the absence of technical guidance, guidance and assistance from policy makers or supporting DPOs. The information provided is limited to general information, so that the head of villages use it to vary according to their respective perceptions, plus the limitations of apparatus human resources and budget availability.

Not to mention if we talk about villages that are minus in terms of their natural potential, then special assistance is needed to realize thematic villages in that place.

Finally, answer the question Are there any suggestions regarding KDT? (question 11) head of villages were very supportive and hoped that if this policy was accompanied by clear technical guidelines, good assistance and financial support that might be added according to the district's capacity.

\section{Conclusions and Suggestions}

\subsection{Conclusion}

Based on the results of research and discussion carried out in advance, it can be concluded as follows: (a) The existing condition of the participation of the Head of village in the Thematic Village Policy in Pamekasan Regency is very good quantitatively because all villages are competing to implement KDT, but when viewed from the degree of participation, it seems low, because participation has not yet reached the level of full understanding of the program due to various factors which influence. (b) Factors influencing the participation of the Head of village in Thematic Village Policy in Pamekasan Regency in addition to supporting factors in the form of regulatory demands, financial support, commitment of the District Government, Commitment of the Head of village, Leadership Model of the Head of village, Similarity of political support, Similarity of alumni and reciprocity, also has inhibiting factors such as the absence of KDT technical guidelines, unclear budget allocations and miscommunication. (c) The ideal model of Head of village Participation in Thematic Village Policy in Pamekasan Regency, should be involved since the concept of the policy was made, discussed, implemented, utilized, evaluated until the emergence of innovations in the implementation of the Policy.

\subsection{Suggestions}

(a) To improve the quality of head of village participation in the Thematic Village Policy in Pamekasan Regency, efforts should be made to be of an administrative nature such as making KDT technical manuals, OVOP socialization, and mentoring from academics. (b) It is necessary to strengthen the supporting factors and minimize the factors inhibiting the participation of the Head of village in Thematic Village Policy in Pamekasan Regency by creating a KDT pilot project that is sustainable and training the head of villages in a team work through various field activities such as leadership training, out bound, etc. (c) It is necessary to replicate the ideal model of Participation of the Head of village in Thematic Village Policy in Pamekasan Regency which is enriched with a touch of Information Technology so that it can follow the flow of the times. Agus Sukristyanto (2018). Governor Election and Political Participation in East Java Advances in Social Science, Education and Humanities Research, volume 191. Atlantis Press.

\section{References}

[1] Agus Sukristyanto. Governor Election and Political Participation in East Java Advances in Social Science, Education and Humanities Research, volume 191. Atlantis Press. (2018).

[2] Creswell, J. N. Research Design: pendekatan Kualitatif, Kuantitatif dan mix, penerjemah Ahmad Fawaid, Yogyakarta, Pustaka Pelajar, (2012).

[3] Fasli Jalal dan Dedi Supriadi. Reformasi Pendidikan dalam Konteks Otonomi Daerah. Jakarta: Depdiknas Bapenas Adicitakaryanusa. Jakarta, (2001).

[4] Kartono, K. Pemimpin Dan Kepemimpinan. Jakarta: PT. Raja Grafindo Persada. (2003).

[5] Moejiono, I. Kepemimpinan dan Keorganisasian, Yogjakarta, UII Press. (2002).

[6] Ritzer, G.\& Goodman, D. J. Teori Sosiologi Modern; Alih bahasa Alimandan, Jakarta, Prenada Media, (2005).

[7] Robert Chambers. Ideas For Development. London: Earthscan. (2005).

[8] Siti Irene Astuti Dwiningrum. Desentralisasi dan Partisipasi Masyarakat Dalam Pendidikan. Yogyakarta: Pustaka Pelajar.(2011).

[9] Slamet, Y. Pembangunan Masyarakat Berwawasan Partisipasi. Surakarta: Sebelas Maret University Press, (1994).

[10] Subarsono, Ag. Analisis Kebijakan Publik: Konsep, Teori dan Aplikasi. Yogyakarta: Pustaka Pelajar, (2015).

[11] Sumaryadi, I. Nyoman., Sosiologi Pemerintahan. Penerbit: Ghalia Indonesia, Bogor. (2010).

[12] Sundariningrum. Klasifikasi Partisipasi. Jakarta: Grasindo, (2001).

[13] Suryadi. Kepemimpinan. Surabaya: Putra Media Nusantara, (2010).

[14] Undang-undang Nomor 25 Tahun 2004 tentang Sistem Perencanaan Nasional.

[15] Peraturan Pemerintah (PP) No. 8 Tahun 2008. Tahapan Tata Cara Penyusunan Pengendalian Dan Evaluasi Pelaksanaan Rencana Pembangunan Daerah.

[16] Peraturan Daerah Kabupaten Pamekasan Nomor 9 Tahun 2019 tentang RPJMD 2018-2023. 